\title{
Advancements in biocatalysis: From computational to metabolic engineering
}

\author{
Aqib Zafar Khan a, Muhammad Bilal b,*, Tahir Rasheed c, Hafiz M. N. Iqbal d,\# \\ a State Key Laboratory of Microbial Metabolism, School of Life Sciences and Biotechnology, Shanghai Jiao Tong University, Shanghai 200240, China \\ b School of Life Science and Food Engineering, Huaiyin Institute of Technology, Huaian 223003, Jiangsu, China \\ c School of Chemistry \& Chemical Engineering, State Key Laboratory of Metal Matrix Composites, Shanghai Jiao Tong University, Shanghai 200240, China \\ d Tecnologico de Monterrey, School of Engineering and Sciences, Campus Monterrey, Ave. Eugenio Garza Sada 2501, Monterrey, N.L., CP 64849, Mexico
}

\section{A R T I C L E I N F O}

\section{Article history:}

Received 11 April 2018

Accepted 9 July 2018

Published 5 December 2018

\section{Keywords:}

Biocatalysis

Enzyme

Metabolic engineering

Synthetic biology

\begin{abstract}
A B S T R A C T
Through several waves of technological research and un-matched innovation strategies, bio-catalysis has been widely used at the industrial level. Because of the value of enzymes, methods for producing value-added compounds and industrially-relevant fine chemicals through biological methods have been developed. A broad spectrum of numerous biochemical pathways is catalyzed by enzymes, including enzymes that have not been identified. However, low catalytic efficacy, low stability, inhibition by non-cognate substrates, and intolerance to the harsh reaction conditions required for some chemical processes are considered as major limitations in applied bio-catalysis. Thus, the development of green catalysts with multi-catalytic features along with higher efficacy and induced stability are important for bio-catalysis. Implementation of computational science with metabolic engineering, synthetic biology, and machine learning routes offers novel alternatives for engineering novel catalysts. Here, we describe the role of synthetic biology and metabolic engineering in catalysis. Machine learning algorithms for catalysis and the choice of an algorithm for predicting protein-ligand interactions are discussed. The importance of molecular docking in predicting binding and catalytic functions is reviewed. Finally, we describe future challenges and perspectives.
\end{abstract}

(C) 2018, Dalian Institute of Chemical Physics, Chinese Academy of Sciences. Published by Elsevier B.V. All rights reserved.

\section{Introduction}

Enzyme production with high-value and applied perspectives in different industrial and medicinal sectors is a pursuit central to modern industry. Among enzyme sources, microbial enzymes are preferred because of their advantageous characteristics such as economic feasibility, rapid microbial growth, overall cost-effective ratio, induce productivity, high yield, high catalytic efficacy, overall stability, and ease of product modification via immobilization, among others [1-3]. Biotechnologists and microbiologists have long considered enzymatic ca- talysis to have enormous potential in diverse fields for manufacturing specialty chemicals and pharmaceuticals, biofuel production, and food processing. High catalytic potentiality, stability, and repeatability of enzymes are characteristic features required for industrial bio catalytic processes [4]. Because of their efficient catalytic activity, biological catalysts or, simply, bio-catalysts are considered attractive for enhancing overall reaction feasibility [5]. Structural, chemical, and stress-based characteristics make enzymes more suitable bio-catalysts compared to their synthetic counterparts [6,7]. Enzymes not only increase reaction rates, but also help to block

\footnotetext{
* Corresponding author. E-mail: bilaluaf@hotmail.com

* Corresponding author. Tel: +52(81)83582000; E-mail: hafiz.iqbal@itesm.mx

DOI: 10.1016/S1872-2067(18)63144-4 | http://www.sciencedirect.com/science/journal/18722067 | Chin. J. Catal., Vol. 39, No. 12, December 2018
} 


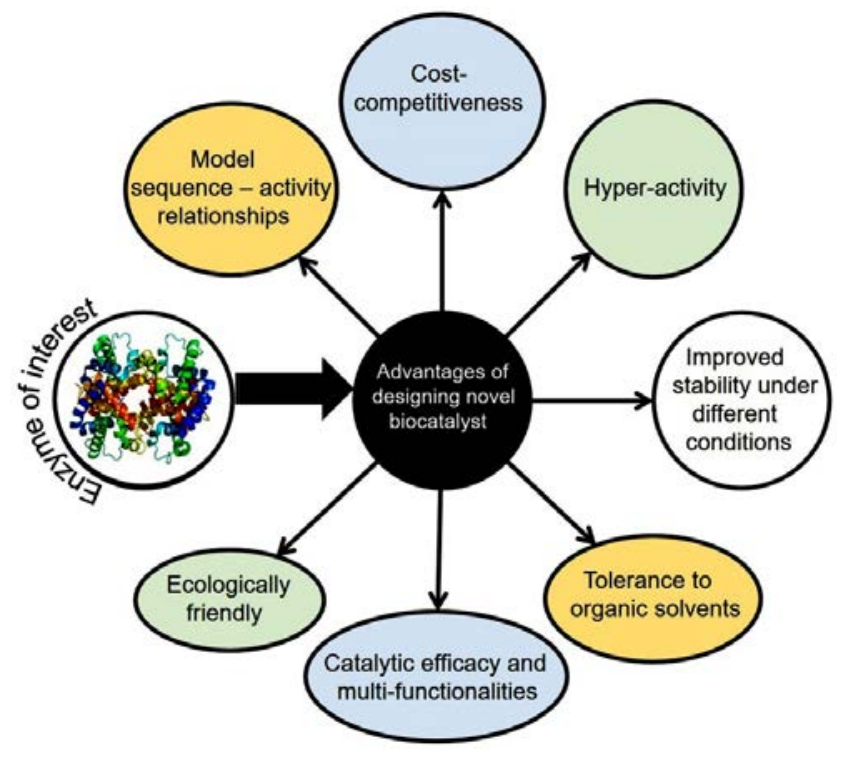

Fig. 1. Advantages of designing novel biocatalysts of interest.

reactions limiting flux towards a target [8]. Fig. 1 illustrates some advantages of designing novel biocatalysts of interest. Despite these advantages, the low stability of enzymes is a significant technical challenge in numerous applications. To overcome such limitations, biocatalytic evaluation and improvement strategies have been developed as shown in Fig. 2 [4].

Many enzymes with efficient catalytic activity in the production of important molecules and reactions within cells have not been discovered [6,9]. However, various protein engineering approaches have been reported to improve the catalytic activity of enzyme-based catalysts. Several in-practice classical strategies for designing catalyst are laborious and time-consuming [10-12]. Therefore, computational tools are required to design catalyst in a short time with the requisite catalytic characteristics [13].

Herein, we highlight the role of synthetic biology and metabolic engineering in catalysis. We first focus on machine learning algorithms for catalysis and the choice of an algorithm for predicting protein-ligand interactions. In the next part, the importance of molecular docking is reviewed, including the prediction of binding and catalytic functionalities. Several advantages and disadvantages of this system are described. Artificial metalloenzymes for creating catalytically novel proteins are presented in the third part. The fourth part emphasizes the role of synthetic biology and metabolic engineering in catalysis aiming to construct highly efficient microbial cell factories as novel platforms for the next-generation bio-economy. We conclude by describing future challenges and perspectives.

\section{Machine learning algorithms for catalysis}

Machine learning algorithms are helpful for building models of unknown proteins by comparative homology based on their sequence and structural characteristics [14,15]. Fig. 3 illustrates a general approach for machine learning of protein (ChR) structure-function relationships [15]. A key limitation to the development of novel biocatalysts is that many experiments

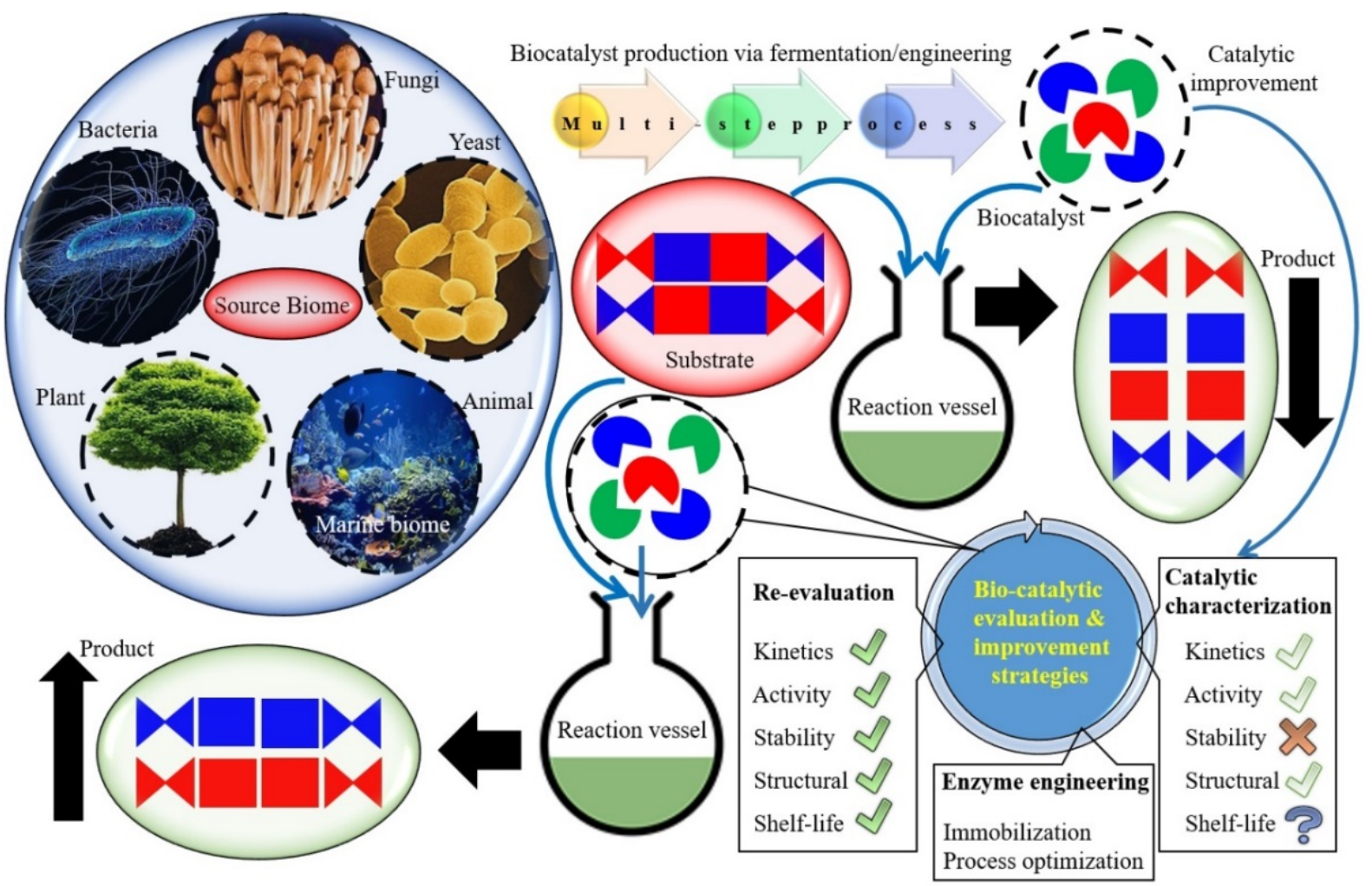

Fig. 2. Biocatalytic evaluation and improvement strategies. A complete overview from biocatalyst (enzyme) production via fermentation and/or engineering to catalytic pathway. The low substrate conversion can be significantly improved by enzyme engineering. Reproduced from Ref. [4], with permission from Elsevier. 
1. structure guided recombination select block boundaries

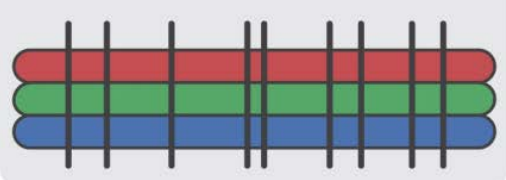

2. chimera characterization: expression \& localization sequence

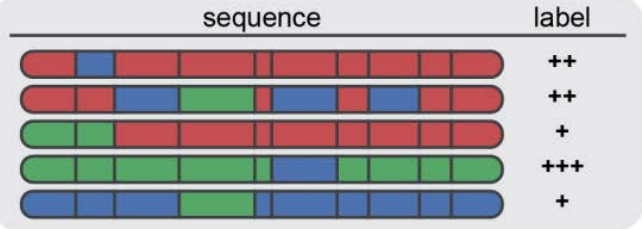

3. statistical modeling
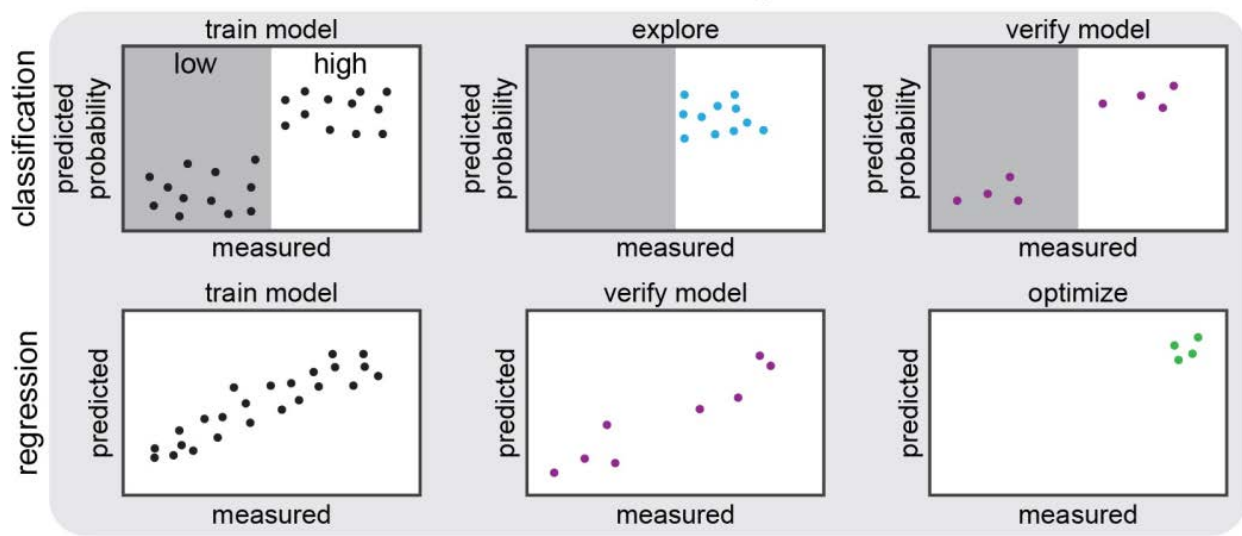

verify model
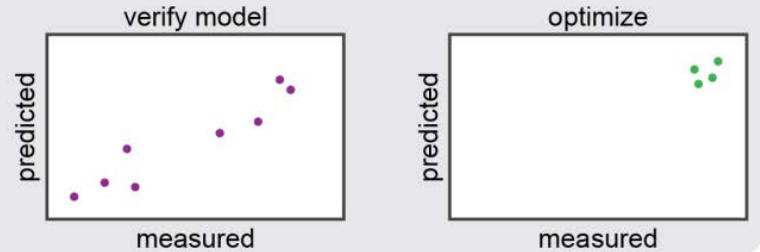

Fig. 3. General approach to machine learning of protein $(\mathrm{ChR})$ structure-function relationships: diversity generation, measurements on a training set, and modeling. Reproduced from Ref. [15], an open access article distributed under the Creative Commons Attribution License.

introduce multiple simultaneous mutations, making it very difficult to determine which is responsible for the improvement $[14,16]$. Machine learning can address this problem [14,15]. One early example of machine learning-based redesign of biocatalysts was ProSAR (protein structure-activity relationship) $[17,18]$. ProSAR was applied in the engineering of a halohydrin dehalogenase for the synthesis of ethyl (R)-4-cyano-3-hydroxybutyrate, a starting material for synthesizing the cholesterol-lowering drug atorvastatin (Lipitor). This resulted in the accumulation of over 35 mutations and a 4000 -fold improvement in volumetric productivity with relatively little screening effort [17].

\section{Choice of an algorithm for predicting protein-ligand interactions}

Algorithms that have received the most attention are support vector machines [19,20], Gaussian Processes [21,22], and Random Forests (RF) [23-25]. These approaches facilitate interpretability, rationalization, and evaluation. Algorithms selection is difficult when studying deep neural networks for protein-ligand interactions [26]. Rather than focusing on whole protein structures in interaction studies, a protein motif along with a ligand are interacted using interpretable confidence-rated boosting algorithms to gain insight into the molecular mechanisms underlying each interaction [27]. Hwang et al. [28] used LBias algorithms to study protein-ligand interactions on the genome-scale for drug development. The algorithm also helps to construct unbinding trajectories using unbiased dynamics and free energy spots using the conformation space network [29].

\section{Substrate-specific target calculation}

Enzymes showing high potential must be engineered such that specific binding ligands can be controlled by binding to new substrate or inhibitors. AutoDock Vina, AutoDock, Glide, Gold, and many other molecular docking tools have been used to examine substrate-ligand binding effects virtually $[30,31]$ (Fig. 4) [32]. These tools show differences in performance in the target system and docked ligand, and therefore show high success rates for the molecules of interest [33-35]. Molecular docking is used to predict all probable binding sites before and after enzyme engineering. This also helps identify mutational sites using a ligand-specific method. AutoDock Vina is a user-friendly tool used as read-to-dock with ligand structures present in databases and is available as a PyMol plugin [36]. In a previous study, sucrose phosphorylase exploited during glycosylation was considered as a solution, but no studies have examined the substantial catalytic activity in the path to arriving at substrate production. On active-site of thermostable sucrose phosphorylase, syndicate docking and simulation were performed to detect mutational hotspots in Thermoanaerobacterium thermosaccharolyticum, which enhanced the activity site size through point mutations [37].

Despite some advantages, molecular docking tools also have limitations such as the generation of reliable receptor-ligand information. After ligand-substrate binding, an enzyme may undergo structural modifications which can cause failure of docking approaches. Additionally, receptor flexibility is protracted by different docking algorithms rather than giving a single two-dimensional picture. However, the probabilities of 


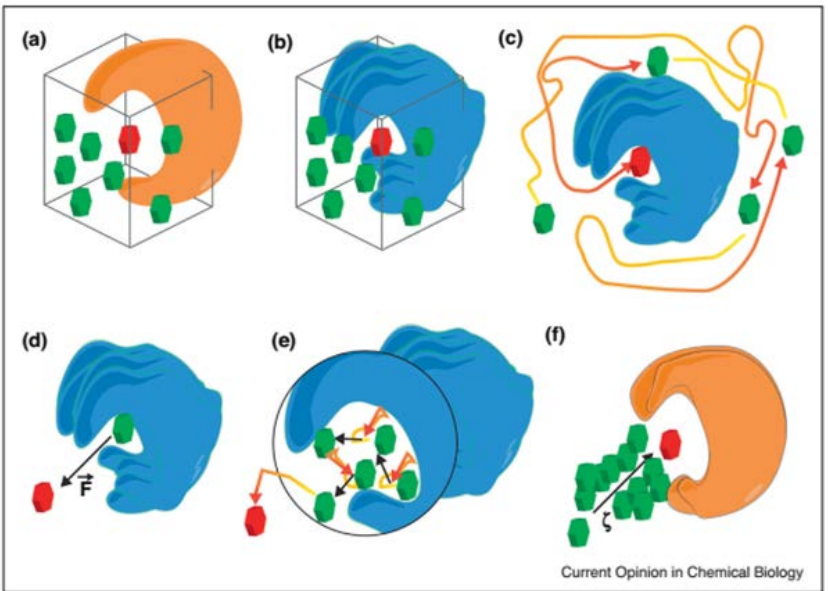

Fig. 4. (a) Molecular docking of a substrate into a static receptor conformation to predict the binding pose and identify promising residues for mutagenesis. (b) Same as (a) but using a structural ensemble of conformations generated by NMR, MD, or using several crystal structures. (c) Binding pose search using a free MD simulation of receptor-ligand complex. (d) Introduction of bias into an MD simulation in the form of a force along a predefined reaction coordinate. The egress path contains information about initial binding residues and ligand access tunnel topology. Methods include adaptive-biasing force, umbrella sampling and steered MD. (e) RAMD is a combination of (c) and (d) for predicting a putative path of ligand egress. An unbiased simulation is carried out until displacement of the ligand becomes trapped in a local energy minimum. An external biasing force with random direction is applied and an unbiased MD continues until completion of ligand egress. (f) The PELE algorithm functions along with a reaction coordinate by placing a ligand of interest in every possible orientation, while at the same time locally perturbing residue orientation in response to the ligand. This introduces limited unbiased dynamics in the protein. Reproduced from Ref. [32], with permission from Elsevier.

false-positive identification of the mutational site and prediction of binding sites are high [38]. A ligand cannot directly bind to a specific site and requires various interactions, making it difficult to simulate the ligand. Therefore, long time-scale molecular dynamics (MD) simulation on the $\mu$ s to ms scale is required to detect these events [39]. These simulations require not only expertise but also high computational power. To resolve this, a computational model introduced through molecular dynamics (SMD) or random accelerated molecular dynamics (RAMD) overcome barriers and ignore favorable interactions regions [40,41]. Both SMD and RAMD approaches can be extended to bio-catalytic applications to study protein targets. Full protein simulation is time-consuming and requires high-speed computation; thus, in 2005, protein energy landscape exploration (PELE) to identify the binding site was introduced [42].

\section{Artificial metalloenzymes}

Because zinc ion is often an essential cofactor, artificial metalloenzymes show high biological function. Therefore, artificial metalloenzymes have become attractive for synthesis applications and competitive with conventional catalysis approaches. Twenty natural amino acids can be used to design an artificial metalloenzyme via de novo synthesis. This approach is based on the construction of a polypeptide sequence that can fold in a well-defined three-dimensional structure. For example, de novo design has been carried out for helical bundles, a common scaffold in several artificial heme proteins [43]. Some key scientific advances in de novo design along with computational methods have been made and reported elsewhere $[44,45]$. The three key parameters in the design of an artificial metalloenzyme include: (1) a transition metal catalyst, (2) a bio-molecular scaffold, and (3) a mode of attachment of the transition metal catalyst to the scaffold. Additionally, available structural information for most of the bio-molecular scaffolds used to date considerably improves the design and optimization for developing new metalloenzyme constructs. The catalytic reaction capabilities of artificial metalloenzymes were reviewed previously [46-50], and thus are not the focus of the current review.

Hydrogenation reactions have been reported utilizing an artificial metalloenzyme (ArM) for avidin protein [51]. Recently, artificial metalloenzymes were applied for several purposes, such as in cell-free extracts [52,53], whole-cell bio-transformations [52,54,55], and in vivo applications $[10,56]$. Through these approaches, the field of artificial metalloenzymes, biorthogonal chemistry, and synthetic biology are used, which enhances catalytic capabilities for producing targeted molecules $[57,58]$. From the industrial perspective, enzyme engineering offers an eco-friendly solution for generating desired catalytic activity [59]. Metals attached to enzymes alter enzyme characteristics; because of their stability, de novo construction of ArMs remain limited [60]. However, a de novo biological catalyst can establish bonds between carbon and silicon $[52,61]$, as well as carbon and boron bonds [62,63]. Therefore, natural enzymes have been modified by introducing non-inherited catalytic activities [56,64]. In another study, an in silico approach in combination with an evolutionary approach were used to produce organophosphate hydrolase [64]. Some other artificial metalloenzymes with promising catalytic functionalities are summarized in Table 1.

\section{Role of Synthetic biology and metabolic engineering in catalysis}

Metabolic engineering enables the construction of highly efficient microbial cell factories as a novel platform for next-generation bio-economies [72]. Three main factors must be considered when evaluating cost-competitiveness: (1) titer, (2) yield, and (3) rate (TYR). Generally, two strategies are used in metabolic engineering: (1) heterologous pathway engineering and (2) overexpression and/or optimization of the host's own metabolism pathway. These strategies enable the manufacture of a large number of diverse commodity chemicals [73,74], novel materials [75], sustainable fuels [76,77], and pharmaceuticals [78,79] by using different renewable feed-stocks as inexpensive energy sources and solid supports. Biocatalyst efficiency and precursor examination are two main characteristics considered in constructing economic microbial cells. Flux analysis of microbial metabolic pathway is often used for cellular construction but face thermodynamic and kinetics 
Table 1

Artificial metalloenzymes with promising catalytic functionalities.

\begin{tabular}{|c|c|c|c|}
\hline Artificial metalloenzyme & Approach & Reaction catalyzed & Ref. \\
\hline Carbenoid transferase & Biotin-(strept)avidin technology & Intermolecular cyclopropanation and C-H insertion & [65] \\
\hline Manganese(V) Porphycene & $-2+2+5-1$ & Hydroxylation of Ethylbenzene & [66] \\
\hline Rhodium Hydroformylase & $\begin{array}{l}\text { Phosphine bioconjugation methods and a } \\
\text { lipid-binding protein (SCP-2L) }\end{array}$ & $\begin{array}{l}\text { Biphasic production of long-chain linear aldehydes } \\
\text { under benign aqueous conditions }\end{array}$ & [67] \\
\hline Diels-Alderase & Organometallic cofactor & Diels-Alder cyclization reactions & [68] \\
\hline Osmium Peroxygenase & Metal-substitution strategy & Dihydroxylation of Alkenes & [69] \\
\hline $\begin{array}{l}\mathrm{Cu}(\mathrm{II}) \text { bounded Lactococcal multidrug } \\
\text { resistance Regulator (LmrR) }\end{array}$ & Supramolecular anchoring Assembly & Friedel-Crafts Alkylation Reactions & [70] \\
\hline Hydroxynitrile Lyase & Amino acid substitutions & $\begin{array}{l}\text { Additions to an aldehyde and catalyzes a } \\
\text { carbon-carbon bond formation }\end{array}$ & [71] \\
\hline
\end{tabular}

barriers that can be resolved by interfering with their related pathways [80-85]. Despite the several benefits of metabolically engineered microbes, overexpression of heterologous genes also may be beneficial because of their effects on flux which lead to production enhancement [86]. Overexpression effects on energy costs and cells can also induce stress [87].

\section{Protein engineering: Rational design and directed evolution}

From a protein engineering perspective, rational design by site-directed mutagenesis (SDM) and directed evolution are novel genetic engineering approaches. The SDM approach is used to introduce point mutations and requires meticulous information concerning the three-dimensional structure and mechanism of the target enzyme. Compared to SDM, random mutagenesis (RM) necessitates no structural information [4]. Remarkably, rationally exchanging only two amino acids can modify an esterase enzyme to a hydroxy nitrile lyase [71]. Guided by structural information of the enzyme, rational design may be the easiest and straightforward enzyme tailoring ap-

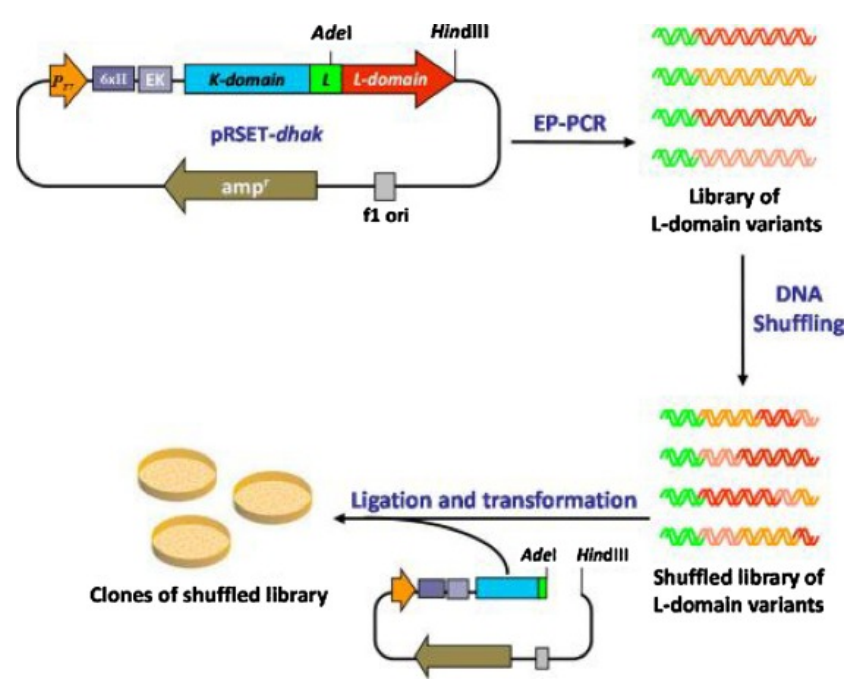

Fig. 5. Directed evolution approach applied to modify phosphoryl donor specificity of dihydroxyacetone kinase from Citrobacter freundii Reproduced from Ref. [91], an open access article distributed under the Creative Commons Attribution License. proach, but the chances of obtaining the desired outcomes often very low, reflecting our lack of understanding of enzyme functions [4]. Pioneering reports of directed evolution were primarily concentrated on enhancing enzymes stability profiles. In this context, organic chemists focused on improving another significant enzyme property: "stereoselectivity". Reetz et al. [88] reported a groundbreaking proof-of-concept approach for improving the enantioselectivity of biocatalysts by directed evolution. Later, DNA shuffling and evolutionary approaches were widely attempted to improve existing properties [89] and identifying unexplored activities of biocatalysts [90]. The directed evolution of halohydrin dehalogenase involved substituting approximately 35 of the 254 amino acids for the manufacture of atorvastatin [17]. It is now possible to modify the biocatalyst, e.g. dihydroxyacetone kinase properties according to predefined designs by directed evolution approaches (Fig. 5) [91].

\section{Concluding remarks and perspectives}

The role of synthetic biology and metabolic engineering in bio-catalysis is reviewed in this manuscript. Machine learning algorithms for bio-catalysis and the choice of an algorithm for predicting protein-ligand interactions are also discussed. Insight is also provided to valorize and predict the binding and catalytic functionalities via molecular docking systems. In summary, machine-based learning strategies have numerous advantages over traditional methods and older algorithms that were developed and refined over approximately a decade. For example, procuring labeled training data, generating a modular library based on useful characteristics, and applying general prediction algorithms, etc., can be further optimized to improve and performance. Moreover, considering modular libraries based on useful characteristics, new catalytic features can be detected and tested as well as compared to existing features.

Artificial metalloenzymes represent a promising technology for exploiting the advantages of transition metal catalysis. Despite its several advantages, this technology suffers from limitations such as its low overall cost-effective ratio, specificity, selectivity, activity, and stability, etc. Such limitations can be overcome by using combinational approaches involving chemical and genetic methods to optimize both the activity and selectivity of artificial metalloenzymes. Additionally, cost-competitiveness can be improved by using cellular facto- 


\section{Graphical Abstract}

Chin. J. Catal., 2018, 39: 1861-1868 doi: 10.1016/S1872-2067(18)63144-4

\section{Advancements in biocatalysis: From computational to metabolic engineering}

Aqib Zafar Khan, Muhammad Bilal *, Tahir Rasheed, Hafiz M. N. Iqbal *

Shanghai Jiao Tong University, China; Huaiyin Institute of Technology, China; Tecnologico de Monterrey, Mexico

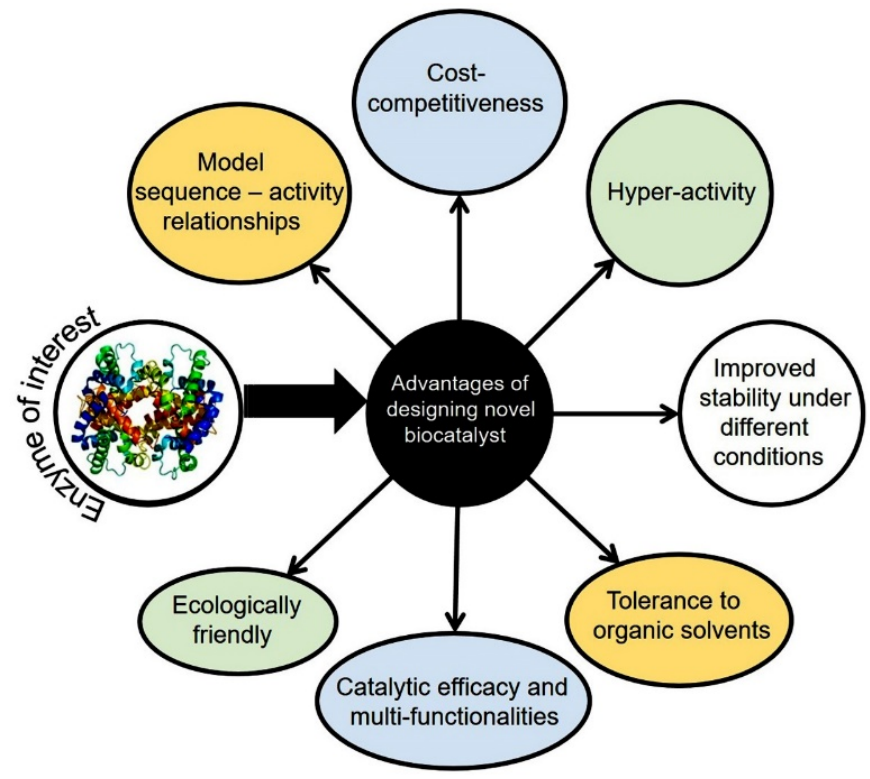

Designing novel biocatalysts with high-values and applied perspectives for different industrial and medicinal sectors is a pursuit central to modern industry. Herein, we highlight the role of synthetic biology and metabolic engineering in bio-catalysis.

ries and gene expression strategies. Modern advancements in computational modeling for industrial fermentation will expedite improvements in catalytic efficacy in the future.

\section{Acknowledgments}

The literature facilities provided by the Shanghai Jiao Tong University, Shanghai, China; Huaiyin Institute of Technology, Huaian, China; and Tecnologico de Monterrey, Mexico are thankfully acknowledged.

\section{References}

[1] N. Gurung, S. Ray, S. Bose, V. Rai, BioMed Res. Int., 2013, 329121/1-329121/0.

[2] M. Asgher, M. Shahid, S. Kamal, H. M. N. Iqbal, J. Mol. Catal. B, 2014, 101, 56-66.

[3] M. Bilal, M. Asgher, R. Parra-Saldivar, H. Hu, W. Wang, X. Zhang, H. M. N. Iqbal, Sci. Total Environ., 2017, 576, 646-659.

[4] M. Bilal, H. M. N. Iqbal, S. Guo, H. Hu, W. Wang, X. Zhang, Int. Biol. Macromol., 2018, 108, 893-901.

[5] M. Goldsmith, D. S. Tawfik, Curr. Opin. Struct. Biol., 2017, 47, 140-150.

[6] U. T. Bornscheuer, G. W. Huisman, R. J. Kazlauskas, S. Lutz, J. C. Moore, K. Robins, Nature, 2012, 485, 185-194.
[7] S. Lutz, S. M. Iamurri, In: Bornscheuer U., Höhne M. (eds) Protein Engineering. Methods in Molecular Biology, Humana Press, New York, 2018, 1685, 1-12.

[8] S. C. Hammer, A. M. Knight, F. H. Arnold, Curr. Opin. Green Sust. Chem., 2017, 7, 23-30.

[9] S. C. Hammer, G. Kubik, E. Watkins, S. Huang, H. Minges, F. H. Arnold, Science, 2017, 358, 215-218.

[10] M. Jeschek, R. Reuter, T. Heinisch, C. Trindler, J. Klehr, S. Panke, T. R. Ward, Nature, 2016, 537, 661-665.

[11] Y. Okamoto, V. Köhler, T. R. Ward, J. Am. Chem. Soc., 2016, 138, 5781-5784.

[12] M. Bersellini, G. Roelfes, Dalton Trans., 2017, 46, 4325-4330.

[13] M. D. Truppo, ACS Med. Chem. Lett., 2017, 8, 476-480.

[14] P. A. Romero, A. Krause, F. H. Arnold, Proc. Nat. Acad. Sci., 2013, 110, E193-E201.

[15] C. N. Bedbrook, K. K. Yang, A. J. Rice, V. Gradinaru, F. H. Arnold, PLoS Comput. Biol., 2017, 13, e1005786/1- e1005786/21.

[16] R. J. Kazlauskas, U. T. Bornscheuer, Nat. Chem. Biol., 2009, 5, 526-529.

[17] R. J. Fox, S. C. Davis, E. C. Mundorff, L. M. Newman, V. Gavrilovic, S. K. Ma, J. Grate, Nat. Biotechnol., 2007, 25, 338-344.

[18] M. Berland, B. Offmann, I. André, M. Remaud-Siméon, P. Charton, Prot. Eng. Design Select., 2014, 27, 375-381.

[19] R. Burbidge, M. Trotter, B. Buxton, S. Holden, Comput. Chem., 
2001, 26, 5-14.

[20] R. N. Jorissen, M. K. Gilson, J. Chem. Inform. Model., 2005, 45, 549-561.

[21] F. R. Burden, J. Chem. Inform. Comput. Sci., 2001, 41, 830-835.

[22] O. Obrezanova, G. Csányi, J. M. R. Gola, M. D. Segall, J. Chem. Inform. Model., 2007, 47, 1847-1857.

[23] P. J. Ballester, J. B. O. Mitchell, Bioinformatics, 2010, 26, 1169-1175.

[24] D. Zilian, C. A. Sotriffer, J. Chem. Inform. Model., 2013, 53, 1923-1933.

[25] P. J. Ballester, A. Schreyer, T. L. Blundell, J. Chem. Inform. Model., 2014, 54, 944-955.

[26] A. Krizhevsky, I. Sutskever, G. E. Hinton, Imagenet classification with deep convolutional neural networks. In: Neural Information Processing Systems (NIPS), 2012, 1097-1105.

[27] P. Greenside, M. Hillenmeyer, A. Kundaje, Pacific Symposium on Biocomputing, 2018, 23, 20-31.

[28] H. Hwang, F. Dey, D. Petrey, B. Honig, Proc. Nat. Acad. Sci. USA, 2017, 114, 13685-13690.

[29] S. D. Lotz, A. Dickson, J. Am. Chem. Soc., 2018, 140, 618-628.

[30] O. Trott, A. J. Olson, J. Comput. Chem., 2010, 31, 455-461.

[31] C. Grebner, J. Iegre, J. Ulander, K. Edman, A. Hogner, C. Tyrchan, J. Chem. Inform. Model., 2016, 56, 774-787.

[32] M. C. C. J. C. Ebert, J. N. Pelletier, Curr. Opin. Chem. Biol., 2017, 37, 89-96.

[33] W. Xu, A. J. Lucke, D. P. Fairlie, J. Mol. Graph. Model., 2015, 57, 76-88.

[34] E. Yuriev, J. Holien, P. A. Ramsland, J. Mol. Recog., 2015, 28, 581-604.

[35] Z. Wang, H. Sun, X. Yao, D. Li, L. Xu, Y. Li, S. Tian, T. Hou, Phys. Chem. Chem. Phys., 2016, 18, 12964-12975.

[36] J. J. Irwin, B. K. Shoichet, J. Chem. Inform. Model., 2005, 45, 177-182.

[37] M. E. Dirks-Hofmeister, T. Verhaeghe, K. De Winter, T. Desmet, Angew. Chem. Int. Ed., 2015, 54, 9289-9292.

[38] M. Lape, C. Elam, S. Paula, Biophy. Chem., 2010, 150, 88-97.

[39] Y. Shan, E. T. Kim, M. P. Eastwood, R. O. Dror, M. A. Seeliger, D. E. Shaw, J. Am. Chem. Soc., 2011, 133, 9181-9183.

[40] M. Klvana, M. Pavlova, T. Koudelakova, R. Chaloupkova, P. Dvorak, Z. Prokop, A. Stsiapanava, M. Kuty, I. Kuta-Smatanova, J. Dohnalek, R. C. Wade, J. Damborsky, P. Kulhanek, J. Mol. Biol., 2009, 392, 1339-1356.

[41] J. Li, P. R. Chen, Nat. Chem. Biol., 2016, 12, 129-137.

[42] K. W. Borrelli, A. Vitalis, R. Alcantara, V. Guallar, J. Chem. Theor. Comput., 2005, 1, 1304-1311.

[43] W. F. DeGrado, C. M. Summa, V. Pavone, F. Nastri, A. Lombardi, Ann. Rev. Biochem., 1999, 68, 779-819.

[44] L. Jiang, E. A. Althoff, F. R. Clemente, L. Doyle, D. Röthlisberger, A. Zanghellini, D. Hilvert, Science, 2008, 319, 1387-1391.

[45] V. Nanda, R. L. Koder, Nat. Chem., 2010, 2, 15-24.

[46] Y. Lu, Curr. Opin. Chem. Biol., 2005, 9, 118-126.

[47] M. D. Mihovilovic, J. Chem. Technol. Biotechnol., 2007, 82, 1067-1071.

[48] T. Ueno, S. Abe, N. Yokoi, Y. Watanabe, Coord. Chem. Rev., 2007, 251, 2717-2731.

[49] A. Pordea, T. R. Ward, Chem. Commun., 2008, 4239-4249.

[50] J. Steinreiber, T. R. Ward, Coord. Chem. Rev., 2008, 252, 751-766.

[51] M. E. Wilson, G. M. Whitesides, J. Am. Chem. Soc., 1978, 100, 306-307.

[52] S. B. J. Kan, R. D. Lewis, K. Chen, F. H. Arnold, Science, 2016, 354, 1048-1051.

[53] P. Dydio, H. M. Key, H. Hayashi, D. S. Clark, J. F. Hartwig, J. Am.
Chem. Soc., 2017,139, 1750-1753.

[54] P. S. Coelho, E. M. Brustad, A. Kannan, F. H. Arnold, Science, 2012, $339,307-310$.

[55] P. Bajaj, G. Sreenilayam, V. Tyagi, R. Fasan, Angew. Chem. Int. Ed., 2016, 55, 16110-16114.

[56] W. J. Song, F. A. Tezcan, Science, 2014, 346, 1525-1528.

[57] P. K. Sasmal, C. N. Streu, E. Meggers, Chem. Commun., 2013, 49, 1581-1587.

[58] T. Völker, F. Dempwolff, P. L. Graumann, E. Meggers, Angew. Chem. Int. Ed., 2014, 53, 10536-10540.

[59] H. Renata, Z. J. Wang, F. H. Arnold, Angew. Chem. Int. Ed., 2015, 54, 3351-3367.

[60] M. L. Zastrow, A. F. A. Peacock, J. A. Stuckey, V. L. Pecoraro, Nat. Chem., 2012, 4, 118-123.

[61] S. Lütz, Angew. Chem. Int. Ed., 2017, 56, 3140-3141.

[62] F. H. Arnold, Angew. Chem. Int. Ed., 2018, 57, 4143-4148.

[63] S. B. J. Kan, X. Huang, Y. Gumulya, K. Chen, F. H. Arnold, Nature, 2017, 552, 132-136.

[64] S. D. Khare, Y. Kipnis, R. Takeuchi, Y. Ashani, M. Goldsmith, Y. Song, B. L. Stoddard, Nat. Chem. Biol., 2012, 8, 294-300.

[65] J. Zhao, D. G. Bachmann, M. Lenz, D. G. Gillingham, T. R. Ward, Catal. Sci. Technol., 2018, 8, 2294-2298.

[66] K. Oohora, H. Meichin, Y. Kihira, H. Sugimoto, Y. Shiro, T. Hayashi, J. Am. Chem. Soc., 2017, 139, 18460-18463.

[67] A. G. Jarvis, L. Obrecht, P. J. Deuss, W. Laan, E. K. Gibson, P. P. Wells, P. C. J. Kamer, Angew. Chem. Int. Ed., 2017, 56, 13596-13600.

[68] T. Di Meo, W. Ghattas, C. Herrero, C. Velours, P. Minard, J. P. Mahy, R. Ricoux, A. Urvoas, Chem. Eur. J., 2017, 23, 10156-10166.

[69] N. Fujieda, T. Nakano, Y. Taniguchi, H. Ichihashi, H. Sugimoto, Y. Morimoto, G. Kurisu, S. Itoh, J. Am. Chem. Soc., 2017, 139, 5149-5155.

[70] J. Bos, W. R. Browne, A. J. M.Driessen, G. Roelfes, J. Am. Chem. Soc., 2015, 137, 9796-9799.

[71] S. K. Padhi, R. Fujii, G. A. Legatt, S. L. Fossum, R. Berchtold, R. J. Kazlauskas, Chem. Biol., 2010, 17, 863-871.

[72] B. W. Biggs, B. De Paepe, C. N. S. Santos, M. De Mey, P. Kumaran Ajikumar, Curr. Opin. Biotechnol., 2014, 29, 156-162.

[73] J. W. Lee, T. Y. Kim, Y. S. Jang, S. Choi, S. Y. Lee, Trend. Biotechnol., 2011, 29, 370-378.

[74] Y. S. Tai, M. Xiong, K. Zhang, Metabol. Eng., 2015, 27, 20-28.

[75] M. Xiong, D. K. Schneiderman, F. S. Bates, M. A. Hillmyer, K. Zhang, Proc. Nat. Acad. Sci. USA, 2014, 111, 8357-8362.

[76] P. Xu, L. Li, F. Zhang, G. Stephanopoulos, M. Koffas, Proc. Nat. Acad. Sci. USA, 2014, 111, 11299-11304.

[77] K. Qiao, S. H. Iman Abidi, H. Liu, H. Zhang, S. Chakraborty, N. Watson, P. Kumaran Ajikumar, G. Stephanopoulos, Metabol. Eng., 2015, 29, 56-65.

[78] Y. Lin, X. Shen, Q. Yuan, Y. Yan, Nat. Commun., 2013, 4, 2603.

[79] K. Thodey, S. Galanie, C. D. Smolke, Nat. Chem. Biol., 2014, 10, 837-844.

[80] A. Singh, K. C. Soh, V. Hatzimanikatis, R. T. Gill, Metabol. Eng., 2011, $13,76-81$.

[81] E. I. Lan, J. C. Liao, Proc. Nat. Acad. Sci. USA, 2012, 109, 6018-6023.

[82] G. Stephanopoulos, ACS Syn. Biol., 2012, 1, 514-525.

[83] M. Tai, G. Stephanopoulos, Metabol. Eng., 2013, 15, 1-9.

[84] K. Qiao, T. M. Wasylenko, K. Zhou, P. Xu, G. Stephanopoulos, Nat. Biotechnol., 2017, 35, 173-177.

[85] P. Xu, K. Qiao, G. Stephanopoulos, Biotechnol. Bioeng., 2017, 114, 1521-1530.

[86] P. Xu, Q. Gu, W. Wang, L. Wong, A. G. W. Bower, C. H. Collins, M. A. G. Koffas, Nat. Commun., 2013, 4, 1409.

[87] L. Zelcbuch, N. Antonovsky, A. Bar-Even, A. Levin-Karp, U. Baren- 
holz, M. Dayagi, A. Brandis, Nucl. Acid. Res., 2013, 41, e98-e98.

[88] M. T. Reetz, A. Zonta, K. Schimossek, K. Liebeton, K. E. Jaeger, Angew. Chem. Int. Ed., 1997, 36, 2830-2832.

[89] Z. Sun, Y. Wikmark, J. E. Bäckvall, M. T. Reetz, Chem. Eur. J., 2016, $22,5046-5054$
[90] H. Renata, Z. J. Wang, F. H. Arnold, Angew. Chem. Int. Ed., 2015, 54, 3351-3367.

[91] I. Sánchez-Moreno, I. Bordes, R. Castillo, J. J. Ruiz-Pernía, V. Moliner, E. García-Junceda, Int. J. Mol. Sci., 2015, 16, 27835-27849.

\title{
生物催化进展：从计算到代谢工程
}

\author{
Aqib Zafar Khan ${ }^{\text {a }}$, Muhammad Bilal ${ }^{\text {b,* }}$, Tahir Rasheed ${ }^{\text {c }}$, Hafiz M. N. Iqbal d,\# \\ 点上海交通大学生命科学与生物技术学院, 微生物代谢国家重点实验室, 上海200240, 中国

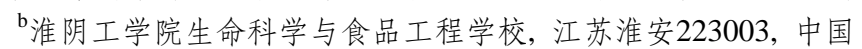 \\ '上海交通大学化学与化学工程学院金属复合材料国家重点实验室, 上海200240, 中国 \\ $\mathrm{d}$ 蒙特雷技术学院工程与科学学院, 蒙特雷64849, 墨西哥
}

摘要: 经过数次技术研究和超常创新战略的大发展, 生物催化逐渐达到工业化水平, 从而受到人们特别的关注. 基于酶值, 通过生物途径生产高附加值化合物和精细工业化学品成为人们最感兴趣的领域之一. 更广泛的众多生物化学路线可由酶 催化来实现, 其中还有一些酶尚未被人们发现. 另一方面, 由于非同源底物和某些化学过程所必需的苛刻条件, 导致酶催 化过程的效率低、稳定性差, 因而限制了生物催化的应用. 因此, 开发具有多催化特征、更高效率和稳定性的绿色催化剂, 成为生物催化的重中之重. 计算科学、代谢工程、合成生物, 以及机器学习路线的运用为新催化剂的工程化提供了新方法. 本文重点介绍了合成生物学和代谢工程在催化中的作用, 讨论了用于催化的机器学习算法和如何选择一种预测蛋白质-配 体相互作用的算法; 为了预测键合和催化功能, 综述了分子对接的重要性; 最后给出了结束语、未来挑战和前景展望.

关键词: 生物催化; 酶; 代谢工程; 合成生物学

收稿日期: 2018-04-11. 接受日期: 2018-07-09. 出版日期: 2018-12-05.

*通讯联系人. 电子信箱: bilaluaf@hotmail.com

\#通讯联系人. 电话: +52(81)83582000; 电子信箱: hafiz.iqbal@itesm.mx

本文的电子版全文由Elsevier出版社在ScienceDirect上出版(http://www.sciencedirect.com/science/journal/18722067). 